\title{
PCDD/F and PCB multi-media ambient concentrations, congener patterns and occurrence in a Mediterranean coastal lagoon (Etang de Thau, France)
}

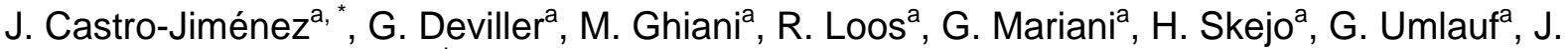

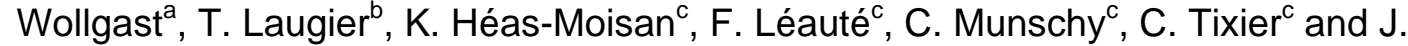 \\ Tronczyńskic
}

\footnotetext{
a European Commission-DG Joint Research Centre, Institute for Environment and Sustainability(IES), TP 290, Via Enrico Fermi, 1. 21020 Ispra (VA), Italy

${ }^{\mathrm{b}}$ Ifremer, Laboratory of Environmental Resources, Bd Jean Monnet, BP 171, 34203 Sète Cedex, France

c Ifremer, Laboratory of Biogeochemistry of Organic Contaminants, BP 21105, 44311 Nantes Cedex 3, France
}

\author{
*: Corresponding author : J. Castro-Jiménez, Tel.: +39 0332 786070; fax: +39 0332 786351, email \\ address : javier.castro-jimenez@jrc.it
}

\begin{abstract}
:
Ambient concentrations, congener patterns and multi-media distribution of PCDD/Fs and PCBs were determined in air, water, sediment and mussels in a semi-enclosed marine ecosystem (Thau lagoon, France). $\quad 22,3,7,8-\mathrm{PCDD} / \mathrm{F}$ and $57 \mathrm{ICES}$ PCB air concentrations $\left(0.2-1.4\right.$ and $31-57 \mathrm{pg} \mathrm{m}^{-3}$, respectively) were typical of rural areas. Concentrations in the water column were very low for PCDD/Fs (163-476 fg L $\mathrm{L}^{-1}$ ) and low for PCBs (138-708 $\mathrm{pg} \mathrm{L}^{-1}$ ). PCDD/F and PCB concentrations found in surface sediment (0.15-1.6 and 2.5-33 $\mathrm{ng} \mathrm{g}^{-1} \mathrm{~d}$.w., respectively) and mussel (13-21 $\mathrm{pg} \mathrm{g}^{-1}$ d.w. and 10-39 $\mathrm{ng} \mathrm{g}^{-1}$ d.w., respectively) were medium levels. PCDD/F congener patterns observed in air, water particulate phase and sediments were similar suggesting direct coupling among these compartments and atmospheric inputs of PCDD/Fs into the lagoon. Conversely, for the same set of samples, similar patterns were not observed for PCBs in the mentioned compartments.
\end{abstract}

Multi-media ambient concentrations and distribution of PCDD/Fs and PCBs in Thau Lagoon provide insight into the POPs behavior in semi-enclosed marine ecosystems.

Keywords: POPs; Air; Sediment; Mussel; Water column 


\section{Introduction}

Persistent organic pollutants (POPs) enter the environment primarily or exclusively as a result of anthropogenic activities. Polychlorinated dibenzo-pdioxins and dibenzofurans (PCDD/Fs) and polychlorinated biphenyls (PCBs) are two important families of POPs. These chemicals bioaccumulate and are considered as potent toxicants capable of producing a wide spectrum of adverse health effects in biota and humans ([Safe, 1984] and [Safe, 1990]). PCDD/Fs occur as unintentional byproducts of chemical manufacturing and incineration processes ([Harrad and Jones, 1992] and [Bruzy and Hites, 1996]) whereas current sources of PCBs are landfills, open burning of products containing PCBs, waste incineration, accidental fires and revolatilization from formerly exposed soils (Cousins and 
1 Jones, 1998; Breivik et al., 2002). PCBs were mainly used by the power industry in

2 electrical transformers, capacitors, hydraulic equipment, and as lubricants.

$4 \mathrm{PCDD} / \mathrm{Fs}$ and PCBs enter the aquatic systems by atmospheric deposition, direct and 5 indirect discharges, and riverine inputs. A low aqueous solubility and vapor pressure, and 6 resistance to extensive chemical and biological transformation characterize these 7 compounds. Their general hydrophobic nature results in high partition coefficients to 8 abiotic and especially biotic particles. PCDD/Fs and PCBs exist in the atmosphere as gases 9 and bound to particles, being temperature an important variable affecting this partition 10 (Schwarzenbach et al. 2003). Once delivered to the water column, the primary removal 11 processes are sedimentation of atmospheric particles and partitioning of the 12 gaseous/dissolved phase contaminants into organic carbon (OC)-rich particles with 13 subsequent settling and accumulation in surface sediments, where contaminant and particle 14 burial is slowed by resuspension and mixing of surface sediments by aquatic organisms.

16 Coastal lagoons represent less than $1 \%$ of the surface covered by oceans and seas, however 17 they are characterized by a high biodiversity and intense primary production leading to both 18 ecological and economical considerable importance (Nixon, 1982). Such is the case of 19 Thau lagoon, one of the largest Mediterranean lagoons. Located on the French

20 Mediterranean coast along the Gulf of Lion (Figure 1), it covers a surface of $75 \mathrm{~km}^{2}$ with an 21 average depth of $4.5 \mathrm{~m}$ and is isolated from the Mediterranean Sea by an offshore bar. The 22 lagoon is connected to the sea North-East by the channel of Sète (90\% of the exchanges) 23 and South-West by the channel de Pisse-Saumes (10\% of exchanges). Winds are often 
1 strong in the area with an average of 118.5 days per year above Beaufort force 5 (data from

2 Météo France), in particular when blowing from North-West (Tramontane). Wind has been

3 described as an important variable influencing the lagoon hydrodynamics (Lazure, 1992).

4 There is an intensive shell farming activity (oysters and mussels) that covers about $20 \%$ of

5 the whole lagoon area and yearly produces about 15000 tons of oysters. (Gangnery et al., 6 2001).

7 Thau lagoon seems to be under intense anthropogenic pressure (urban, industrial, 8 agricultural and shell farming activities). The biggest town (Sète) and most of urban 9 activities are located in the Eastern part of the lagoon. A considerable increase of 10 population in the area during the summer months is contributing to the anthropogenic 11 impact. The results of the French Monitoring Network (RNO Réseau National 12 d'Observation) show high contamination of the lagoon sediments by hydrophobic organic 13 compounds compared to other Mediterranean lagoons, especially by polycyclic aromatic 14 hydrocarbons (PAHs) and to a lesser extent by PCBs (Tronczyński, 1998; Leauté et al. 15 2007). However, no information on PCDD/Fs ambient levels in Thau lagoon is available 16 yet. A better knowledge of the fate and dynamics of POPs in this semi-enclosed marine 17 ecosystem is needed in order to apprehend their long-term impacts. The main objectives of 18 this work were: (1) to obtain ambient concentrations, congener patterns and multi-media 19 distribution of PCBs and PCDD/Fs in air, water column, mussel and surface sediment from 20 Thau Lagoon; (2) to generate a data set on multi-media ambient concentrations that serves 21 as a first step for POPs fate modeling validation and future risk assessment in this 22 ecosystem. In addition, some specific aspects regarding the atmospheric input of the 23 pollutants studied will be discussed. 


\section{$1 \quad$ Materials and methods}

$2 \quad$ Sampling

3 Locations of all sampling sites are detailed in Figure 1. Air samples were collected in

4 November 2005 by using high volume samplers at two sites: Ifremer Institute (IF) located

5 on the South shore and Bouzigues (BZ), a small village on the North shore of the lagoon.

6 Air particle phase was retained by using a $102 \mathrm{~mm}$ diameter quartz fibre filter (QFF)

7 whereas the gas phase was trapped with a polyurethane foam (PUF) plug of $65 \mathrm{~mm}$

8 diameter, $50 \mathrm{~mm}$ length and a raw density of $30 \mathrm{~kg} \mathrm{~m}^{-3}$. Volumes of $\sim 400 \mathrm{~m}^{3}$ were

9 collected for each sample (5 samples at IF and 4 at BZ) except for the last one taken at IF

10 site where a volume of $\sim 200 \mathrm{~m}^{3}$ was sampled.

11 Lagoon water was sampled from a boat also in November 2005 by using pre-equilibrated

12 Teflon tubing and a Teflon membrane pump (ASTI, France) operated with compressed

13 nitrogen. The sample was collected in stainless steal $(\mathrm{StS})$ containers. Four samples $(\sim$

14 120L) were taken from the lagoon (T12, T11, C4 and T2) and an additional sample ( 80L)

15 was also collected at the riverine reference station (outlet of the river Véne, RV) (Figure 1).

16 Once in the laboratory samples were filtered (GFF). The filtrated water was collected in

17 clean StS containers and PCDD/F and $\mathrm{PCB}{ }^{13} \mathrm{C}$-labeled internal standard mixtures were

18 added. Filtrates were then passed through a pre-cleaned (MiliQ-UV and sequential soxhlet

19 extraction with methanol, acetonitrile and dichloromethane, $8 \mathrm{~h}$ each) and pre-conditioned

20 (methanol) 50g Amberlite ${ }^{\mathrm{TM}} \mathrm{XAD}-2$ Teflon column at a flow $\leq 80 \mathrm{~mL} / \mathrm{min}$ (Tronczyński et

21 al., 2004, 2005a). The water sample was sucked using a peristaltic pump. Columns were

22 dried by passing air using a vacuum pump. Elution of XAD-2 columns was performed with 
1 dichloromethane. $\mathrm{Na}_{2} \mathrm{SO}_{4}$ anhydrous (baked at $450{ }^{\circ} \mathrm{C} / 8 \mathrm{~h}$ ) was added, the samples were

2 placed in the freezer for transport and then stored until further processing at the laboratory.

4 Both surface sediments and mussels were collected in May 2004. Surface sediment samples

5 were collected by divers at three sites along the lagoon (West, medium and East areas of

6 the lagoon) using Teflon sediment corers. The results presented in this study were obtained

7 from the analysis of the first centimeter of the sediment core. Before analysis, sediments

8 were homogenized, freeze-dried and sieved $(<2 \mathrm{~mm})$ (Tronczyński et al., 2005b).

9 A minimum of 50 mussels (Mytilus galloprovincialis) of homogeneous size were collected

10 by hand from each of the three shellfish areas along the lagoon (Figure 1) and depurated in

11 decanted water from the site for $24 \mathrm{~h}$. The mussels were further shucked, homogenized and

12 stored at $-20^{\circ} \mathrm{C}$ before freeze-drying. Both freeze-dried sediment and mussel samples were

13 stored in the dark at room temperature until analysis (Munschy et al., 2005a).

15 Analytical determinations

$16 \mathrm{PCDD} /$ Fs considered in this work were the $2,3,7,8$ congeners since they have been

17 described as the most toxic ones (Van den Berg et al., 1998), whereas PCBs were 28, 52,

$18101,118,153,138$ and 180 congeners also referred in the text as the 7 ICES (International

19 Council for the Exploration of the Sea). Air and water samples were analyzed at the Joint

20 Research Centre laboratories whereas sediment and mussels sample analyses were carried

21 out at Ifremer laboratories. 


\section{$1 \quad$ Air and water samples}

2 QFFs and PUFs were Soxhlet extracted separately with n-hexane/acetone (220:30 v/v) for

$348 \mathrm{~h}$ after being spiked with internal standards $\left(16{ }^{13} \mathrm{C}\right.$-labelled 2,3,7,8-chlorine-substituted

4 congeners with $400 \mathrm{pg}$ each, except OCDD with $800 \mathrm{pg}$ ). Extract purification was executed

5 with an automated clean-up system (Power-Prep P6, from Fluid Management Systems,

6 Inc., Watertown, MA, USA). The purification method was previously described by Abad et

7 al. (2000). Prior to injection, syringe ${ }^{13} \mathrm{C}$-labelled standards were added to the extracts to

8 determine the recoveries of the internal standards.

9 Regarding water samples, dichloromethane extracts were filtered with pre-cleaned glass

10 wool, concentrated, treated with concentrated $\mathrm{H}_{2} \mathrm{SO}_{4}$ and cleaned up as indicated for air

11 samples. GFF were thawed, cut into small pieces and transferred into $33 \mathrm{~mL}$ ASE®

12 (Dionex) cartridges. ${ }^{13} \mathrm{C}$-labelled $\mathrm{PCDD} / \mathrm{F}$ and $\mathrm{PCBs}$ internal standard mixtures were

13 added. The filters were extracted using the Dionex ASE® 300 applying in a $1^{\text {st }}$ extraction

14 methanol (3 cycles each with a static time of 5 min at $75^{\circ} \mathrm{C}$, heat-up time of 5 min, a flush

15 volume of $100 \%$, a purging time of 60 s and a pressure of $1500 \mathrm{psi}$ ) and in a $2^{\text {nd }}$ extraction

16 hexane (same parameters as for methanol), respectively. The methanol and hexane phases

17 were combined in a separatory funnel. The methanol phase was extracted three more times

18 with $\sim 20 \mathrm{~mL}$ of hexane and all hexane phases were combined and concentrated to $10 \mathrm{~mL}$.

19 From this point on samples were treated as indicated above for the XAD extracts.

20 Quantification of PCDD/Fs and PCBs was based on isotope dilution using a high resolution

21 gas chromatography - high resolution mass spectrometry (HRGC-HRMS). The method has

22 been previously described (Castro-Jiménez et al., 2008). 
2 The analytical protocols for extraction, cleanup and analysis have been previously

3 described (Munschy et al., 2005a, 2005b; Tronczyński et al., 2005b; Johansson et al.,

4 2006). Briefly, approximately $5 \mathrm{~g}$ (dry weight, d.w.) of mussel sample or $7 \mathrm{~g}$ d.w. of

5 sediment were extracted by pressurised solvent extraction (ASE, Dionex Corp., CA) with

6 dichloromethane. For mussel samples, the separation of co-extracted lipids was performed

7 by gel permeation chromatography (GPC). The purified mussel and sediment extracts were

8 concentrated and then further purified and fractionated on a two layer silica/alumina

9 column. Quantification of PCDD/Fs was performed by isotopic dilution using HRGC-

10 HRMS whereas PCBs were analysed by HRGC fitted with two electron capture detectors

11 using two columns.

13 Quality assurance/Quality control

14 QFF were baked at $450^{\circ} \mathrm{C}$ for $6 \mathrm{~h}$ whereas PUFs were soxhlet extracted during at least $24 \mathrm{~h}$

15 with acetone and then dried in a dissicator under vacuum before use. Both cleaned QFF and

16 PUF were wrapped in n-hexane rinsed aluminum foil and placed in a Teflon sealed metallic

17 transport container. Transport (clean filters and PUFs), field, and procedural blanks were

18 collected and processed together with the samples. Field and transport blank values were

19 below the limits of detection (LODs) or at least three times lower than the analyte value for

20 all compound studied, except for PCB-118 that exceeded this QA/QC threshold in some of

21 the air samples. A breakthrough test was performed by placing a smaller PUF plug in series

22 separated $\sim 1 \mathrm{~cm}$ from the main PUF in the sampling head. Breakthrough rates for PCDD/Fs

23 were not possible to be calculated due to the fact that the concentrations found in the gas 
1 phase (PUFs) both for the sample and the breakthrough PUFs were under the LOD ( $1 \mathrm{fg} \mathrm{m}^{-}$

$2{ }^{3}$ ) whereas the breakthrough rate for $\sum \mathrm{PCB}$ in the condition of the sampling period was

3 estimated to be less than 10\%. Extraction blanks (QFF and PUFs) were processed for each

4 batch of samples.

5 Regarding water samples, extraction and clean-up analytical blanks were carried out to 6 check background levels. PCDD/F and PCB recoveries for the air gas and particular phases

7 (PUFs and QFF) and for the water particulate phase (GFF) were in compliance with the 8 specifications of EPA 1613 and EPA 1668 methods, respectively (U.S. EPA., 1994, 1999).

9 However, PCDD/Fs recoveries in the water dissolved phase (XAD) were very low not 10 allowing quality congener quantifications except for the river water sample (RV) where 11 recoveries were sufficient to calculate a LOD. Therefore, $\mathrm{PCDD} /$ Fs dissolved water phase 12 concentrations were not taken into account in the present work except for the RV sample.

13 LOD for PCDD/Fs in water samples varied from 1-5 $\mathrm{fg}^{-1}$.

14 PCB recoveries in the dissolved phase were also low ranging from $16-53 \%$ except in only 15 one sample (T2) where $\mathrm{HxCB}$ and $\mathrm{HpCB}$ internal standards were less than $10 \%$. Even if the 16 signal to noise ratio and the low blank levels found in all samples were enough to allow 17 quality quantification of the studied PCB congeners, a limited used of those data was 18 decided being mainly relegated to generation of congener fingerprints (relative 19 composition) in the dissolved water phase and subsequent discussion. Total concentrations

20 (dissolved + particulate phase) were only considered to compare levels with literature.

21 In order to calculate PCB recoveries in mussel and sediment samples, recovery surrogates

22 (CB 30, CB 198, CB 209, TCN) were added to each sample before extraction and were 23 used to control the recovery efficiency of the overall process. However, results were not 
1 corrected for recoveries (Johansson et al., 2006). In our laboratory, the average recoveries

2 of internal standards in biota are: CB30 78\%, TCN 80\%, CB198 97\% and CB209 98\%

3 ( $\mathrm{n}=65)$ and in sediments are: CB30 81\%, TCN 84\%, CB198 80\% and CB209 78\% (n=25).

4 For PCDD/Fs, ${ }^{13} \mathrm{C}$ labelled congeners were added before extraction and calculations were

5 made by isotopic dilution method (Munschy et al., 2005b). Blanks and certified material

6 analyses were included within every batch of six to eight samples. The laboratory routinely

7 participates in the QUASIMEME (Quality Assurance of Information for Marine

8 Environmental Monitoring in Europe) intercomparison exercises for all analysed

9 contaminants.

\section{$11 \underline{\text { Materials }}$}

12 TE-1000BL PUF high volume samplers were employed (Tisch Environmental, Inc. USA).

13 PUF plugs were obtained from Klaus Ziemer GmbH (Langerwehe, Germany), QFF (QMA-

144 type) and GFF were from Whatman International Ltd (Brentford, Middlesex, UK).

15 Amberlite $^{\mathrm{TM}}$ XAD-2 was from Supelco (Bellefonte, Pennsylvania, USA). Teflon columns

16 used for water sampling were SeaStar Ltd type (37 $\mathrm{cm}$ length x $19 \mathrm{~mm}$ i.d.). All organic

17 solvents were dioxin analysis grade from Sigma-Aldrich (Buchs SG, Switzerland). All

18 gases (Alpha gaz, Italy) used were ultra pure grade suitable for PCDD/Fs analysis. Pre-

19 packed multi-layer silica, basic alumina, and carbon columns were obtained from Fluid

20 Management Systems (FMS) Inc. (Watertown, MA, USA). The standard mixture of native

217 ICES PCB used was PCB mix3 (Dr. Ehrenstorfer GmgH, Augsburg, Germany) and for

$22{ }^{13} \mathrm{C}$-labelled congeners, 68-LCS from Wellington Laboratories (Guelph, Ontario, Canada).

23 EPA-1613CVS, EPA1613LCS+MDF-12346789 and EPA-1613ISS were native, ${ }^{13} \mathrm{C}-$ 
1 labelled internal and recovery standards, respectively for $17 \mathrm{PCDD} / \mathrm{Fs}$ also obtained from

2 Wellington Laboratories.

$4 \quad$ Results and discussion

6 Results on PCDD/Fs and PCBs in the studied matrixes from Thau lagoon are presented in

7 Tables 1 and 2, respectively whereas values extracted from the literature for comparison are 8 compiled in TS1 and TS2 in supporting information.

$10 \quad$ Ambient concentrations

11 Air

12 2,3,7,8-PCDD/Fs air concentrations (particle + gas phase) at IF site ranged from 0.3 to 1.4

$13 \mathrm{pg} \mathrm{m}^{-3}$ (16 to 26 WHO-TEQ $\mathrm{fg} \mathrm{m}^{-3}$ ) whereas for BZ site varied from 0.2 to $0.8 \mathrm{pg} \mathrm{m}^{-3}$ (7 to

$1423 \mathrm{WHO}$-TEQ $\mathrm{fg} \mathrm{m}^{-3}$ ). PCDD/Fs were almost exclusively found to be associated to the air

15 particulate phase. Concentrations observed at both locations were low, typical of those 16 reported for rural areas in Europe, and North America (Lohmann and Jones, 1998; Cleverly

17 et al., 2007). Values found in other aquatic environments such as the Lake Maggiore

18 (located in a semi-rural area) in Northern Italy and from rural areas in Catalonia (Spain) are

19 also within the same range (Abad et al., 2004; Castro-Jiménez et al., 2005, 2008) (Table S1, 20 supporting information).

21

$22 \sum$ PCBs air concentrations reported in this study does not include the congener 118 (see

23 QA/QC section). $\sum \mathrm{PCB}$ air concentrations (particulate + gas phase) found at IF site ranged 
1 from 31 to $48 \mathrm{pg} \mathrm{m}^{-3}$ whereas in site BZ varied from 31 to $57 \mathrm{pg} \mathrm{m}^{-3}$ (Table 2). PCBs were

2 predominately in the gas phase. This fact has been previously reported (Mandalakis et al.,

3 2002; Totten et al., 2004; Hornbuckle et al., 2006). Concentrations within the same order of

4 magnitude were found in Venice lagoon, in air masses coming from the sea, in Lake

5 Maggiore and in a background/rural site in Crete, Greece (Mandalakis et al., 2001;

6 Gambaro et al., 2004; Manodori et al., 2006; Vives et al., 2007) (Table S2 supporting

7 information).

$9 \mathrm{PCDD} / \mathrm{Fs}$ and $\mathrm{PCBs}$ concentrations at both sampling sites were within the same order of 10 magnitude, indicating a homogeneous situation at both shores of the lagoon along the 11 North-South axis. Indeed a Student's t test $(\alpha=0.05)$ confirmed that there were no

12 significant differences between the two sites for the air concentrations of PCDD/Fs $13(\mathrm{P}=0.33)$ and $\mathrm{PCBs}(\mathrm{P}=0.79)$.

15 Meteorological variables influence

16 The weather conditions during the sampling week, where precipitation (on $14^{\text {th }}$ and $15^{\text {th }}$ 17 November) and wind peaks up to $9 \mathrm{~m} \mathrm{~s}^{-1}$ were registered (Météo France, station from Sète), 18 might have favored the low concentrations found in the area, specifically for some days. 19 Higher wind speeds are associated with greater height of the mixed boundary layer (more 20 turbulent sampling conditions) and therefore an effect of pollutant dilution may occur under 21 these conditions (Lohmann et al., 1999; 2003). Wind blew predominantly from North/West 22 (NW) during the sampling period except for a short gap (in the beginning and the end of the 23 period) where it blew from North-North/East (N-NE) (Figure 2). 
1 Principal components analysis (PCA) was applied to identify the main relationships among

2 meteorological variables and $\sum \mathrm{PCDD} / \mathrm{Fs}$ and $\sum \mathrm{PCBs}$ air concentrations. As measurement

3 units of the different variables studied were not homogeneous, the principal components

4 were extracted from the correlation matrix (Legendre and Legendre, 1998). The first two

5 principal components explained $67 \%$ of the total variance $(\mathrm{PC} 1=49 \%$; $\mathrm{PC} 2=18 \%)$. The

6 main relationships among variables are shown in the factor loading plot (Figure 3).

$7 \quad \mathrm{PCDD} / \mathrm{Fs}$ air concentrations were not correlated with local atmospheric conditions whereas

8 PCBs air concentrations during the sampling week were clearly linked to air temperature,

9 humidity and nebulosity (Figure 3). This observation is in agreement to other results

10 reported in the literature where air temperature has been identified as an important variable

11 affecting PCB atmospheric concentrations (Wania et al., 1998; Simcik et al., 1999; Currado

12 and Harrad, 2000).

13 Although not statistically relevant, the wind speed seemed to have an influence on the

14 pollutant concentrations in air. Thus, the lowest PCDD/Fs and PCBs concentration at IF

15 and BZ sites were found in general during the intervals of higher wind speeds, especially

16 for IF site (Figure 2 and Table 1). However, in spite of some wind peaks observed the

17 average wind speed during the sampling period was $\sim 5 \mathrm{~m} \mathrm{~s}^{-1}$. Harrad and Mao (2004)

18 reported that PCB air concentrations were negatively correlated to wind speed only when

19 wind speeds were higher than $4.4 \mathrm{~m} \mathrm{~s}^{-1}$. This value is very close to the one observed in

20 Thau lagoon and the phenomenon described may explain our observations. 


\section{Water}

2 Concentrations were reported only for the particulate phase except for the RV sample (see

3 QA/QC section) where total concentration (dissolved + particulate) is reported. 2,3,7,8-

4 PCDD/Fs concentrations in the water column from Thau Lagoon (Table 1) varied from 163

5 to $476 \mathrm{fg} \mathrm{l}^{-1}$ (4 to 9 WHO-TEQ fg $\mathrm{l}^{-1}$ ). PCDD/Fs measured in RV were predominantly

6 found in the particulate phase and exhibited a concentration of $2770 \mathrm{fg}^{-1}$ (53 WHO-TEQ

$7 \mathrm{fg}^{-1}$ ). The higher concentration observed in RV can be explained by the higher suspended

8 particulate mater (SPM) load in the waters from the river than in the lagoon waters. In fact,

9 when normalizing the PCDD/F concentration by the SPM content, concentrations of 247

10 and $223 \mathrm{pg} \mathrm{g}^{-1}$ d.w. were obtained for RV and T12, respectively. Lower values were

11 obtained in the central and western parts of the lagoon $\left(89,82\right.$ and $52 \mathrm{pg} \mathrm{g}^{-1}$ d.w. at T11, C4

12 and $\mathrm{T} 2$, respectively).

13 Few data are available in the literature on PCDD/Fs measurements in water. For instance,

14 levels found in Thau lagoon were lower than those reported for various aquatic systems

15 such as, non anthropogenic impacted Japanese coastal areas, the central part of Venice

16 Lagoon, Italy or the Raritan Bay/Hudson River Estuary, USA (Hashimoto et al., 1995;

17 Lohmann et al., 2000; Dalla Valle et al., 2003) (Table S1, supporting information).

$19 \sum 7$ ICES PCBs (dissolved + particulate phase) concentrations determined in the water 20 column from Thau Lagoon ranged from 138 to $708 \mathrm{pg} \mathrm{l}^{-1}$, whereas a value of $390 \mathrm{pg} \mathrm{l}^{-1}$ was

21 found in the RV sample (Table 2). PCBs were found predominantly associated to the

22 dissolved water phase, especially the lower congeners $(80-95 \%)$. This fact has already 
1 been described in the literature for other aquatic systems (Zeng et al., 2002; Maldonado and

2 Bayona, 2002).

3 Concentrations within the same order of magnitude were found for a larger set of PCB

4 congeners in the waters of San Diego Bay, California (Zeng et al., 2002) and in Lake

5 Michigan, in USA (Pearson et al., 1996). Much higher concentrations were found for the 7

6 ICES PCBs in the Daya Bay, a semi-enclosed and anthropogenic impacted bay located in

7 Southern China, (Zhou et al., 2001). Lower PCB concentrations have been reported for

8 other coastal areas or open seas such as, the Black and Baltic seas (Bruhn and McLachlan,

9 2002; Maldonado and Bayona, 2002; Wodarg et al., 2004) (Table S2, supporting

10 information).

12 Sediments

13 Results on PCDD/Fs were available for sediments at sampling sites T10 and T12 where 14 concentrations of $150 \mathrm{pg} \mathrm{g}^{-1}$ d.w. (3 WHO-TEQ $\mathrm{pg} \mathrm{g}^{-1}$ d.w.) and $1660 \mathrm{pg} \mathrm{g}^{-1}$ d.w. (14 WHO-

15 TEQ $\mathrm{pg} \mathrm{g}^{-1}$ d.w.) for the sum of the 17 congeners were found, respectively. This higher 16 concentration observed at the Eastern part can not be attributed to a higher sediment 17 organic carbon (OC) content at T12, since values were $4.2 \%$ at $\mathrm{T} 12$ site, and $5.1 \%$ at $\mathrm{T} 10$.

$19 \mathrm{PCDD} / \mathrm{F}$ sediment concentrations within the same order of magnitude were measured in 20 fresh water locations in the UK, where the main sources of PCDD/Fs were thought to be 21 atmospheric (Rose and McKay, 1996). Levels reported for Lake Maggiore sediments where 22 atmospheric inputs have also been identified as major source of PCDD/Fs to the lake were 23 as well within the same order of magnitude (Castro-Jiménez et al., 2005, 2008). Higher 
$1 \mathrm{PCDD} / \mathrm{F}$ levels were reported for an impacted estuarine system (Houston ship Channel,

2 USA) or for sediments from industrially influenced coastal areas in Southern and Easter

3 Spain (Eljarrat et al., 2005; Suarez et al., 2006). Comparing to another coastal lagoon,

4 levels at T12 were slightly higher than PCDD/F concentrations found in sediments from

5 different parts of Venice Lagoon, except for the industrial channels where a much higher

6 concentration was reported (Dalla Valle et al., 2003) (Table S1, supporting information).

$7 \quad \sum \mathrm{PCB}$ concentrations in sediments from the lagoon ranged from 2.5 to $33 \mathrm{ng} \mathrm{g}^{-1}$ d.w.

8 (Table 2). Lower values were measured at the western (T3) and middle (T10) part of the

9 lagoon (Figure 1) whereas the highest concentration was found at the eastern part (T12) as

10 occurred with PCDD/Fs. Again, the spatial variability observed for the contaminant

11 concentrations could not be solely attributed to different sediment OC contents $(9.2,5.1$,

12 and $4.2 \%$ at $\mathrm{T} 3, \mathrm{~T} 10$ and $\mathrm{T} 12$, respectively).

13 PCB concentrations in Thau were comparable with values reported in the literature for

14 various fresh and coastal water ecosystems (Table S2, supporting information) such as,

15 various Mediterranean coastal lagoons, the Lake Maggiore, the Daya Bay, the Lake Taihu

16 (China) and the Quingdao coastal sea also located in China (Moret et al., 2001; Zhou et al.,

17 2001; Zhang and Jiang, 2005; Gómez-Gutiérrez et al., 2007; Pan et al., 2007; Vives et al., 18 2007).

20 Mussels

21 2,3,7,8-PCDD/F concentrations ranging from 13 to $21 \mathrm{pg} \mathrm{g}^{-1}$ d.w. (0.7 to 1 WHO-TEQ pg

$22 \mathrm{~g}^{-1}$ d.w.) were found for the analyzed mussels in the lagoon. The highest value was

23 observed in the western part of the lagoon (M1) although only a slight difference in the

24 concentrations along the lagoon was found (Table 1). PCDD/Fs concentrations in mussels 
1 reported for the English Channel and the Atlantic French coast (Vilaine river bay) are in the

2 same range (Munschy et al., 2005b). The observed values in Thau lagoon were below the

3 threshold of 4 WHO-TEQ pg g ${ }^{-1}$ w.w. (wet weight) set by the European Commission for

4 fishery products for human consumption (European Commission, 2006).

5 Data on PCDD/Fs in shellfish are quite numerous. However, different ways of data 6 reporting and different studied species make data comparison difficult. Moreover, results 7 are rarely associated with the sampling period, despite a significant influence of shellfish 8 sexual maturity (spawning season and lipid content) on the contamination levels. Therefore, 9 the ranges reported for mussels are usually broad. PCDD/Fs concentration in various types 10 of mussel reported for different aquatic systems are slightly higher than those found in 11 Thau lagoon (Petreas et al., 1992; Bayarri et al., 2001; Abad et al., 2002, 2003; Knutzen et 12 al., 2003) (Table S1, supporting information).

$13 \sum \mathrm{PCB}$ exhibited concentrations in mussels ranged from 10 to $39 \mathrm{ng} \mathrm{g}^{-1}$ d.w. Lower values 14 were observed at the western (M1) and middle (M4) part of the lagoon and the highest at 15 the eastern part (M2). This distribution was also observed in sediments. On the other hand, 16 the PCB concentration distribution appears to be the opposite than the one observed for $17 \mathrm{PCDD} / \mathrm{Fs}$ in mussels where the highest concentration was found in the western part of the 18 lagoon as indicated above. Concentrations within the same order of magnitude were found 19 in mussels from various spots in different marine locations (Porte and Albaigés 1993; Lee 20 et al., 1996; Bayarri et al., 2001; Piersanti et al., 2006) (Table S2, supporting information). 


\section{$1 \quad$ Congener patterns}

$3 P C D D / F s$

$4 \mathrm{PCDD} / \mathrm{F}$ congener patterns in the environmental compartments studied are presented in

5 Figure 4. Air samples for the different days of the studied period at both sites exhibited

6 very similar PCDD/F congener patterns indicating a homogeneous situation in both shores

7 of the lagoon. OCDD and HpCDD predominated in the pattern, followed at a lower

8 percentage, by $\mathrm{HpCDF}$ and $\mathrm{OCDF}$. This congener distribution ("sink" profile) has been

9 described in the literature as the resultant patter from combustion sources after preferential

10 removal of lower chlorinated dioxins and furans by atmospheric processes (Brubaker and

11 Hites, 1997). Air patterns found in Thau lagoon were in agreement with those reported for

12 various rural areas influenced by deposition of these pollutants after long range transport

13 (Tysklind et al., 1993; Lohmann and Jones., 1998; Castro-Jiménez et al., 2005, 2008;

14 Cleverly et al., 2007).

16 Particulate water phase and surface sediment patterns were also dominated by HpCDD and

17 OCDD and were similar in all sampling sites suggesting a homogeneous situation in the

18 lagoon and a direct coupling between these compartments.

19 OCDD and 2,3,7,8-TCDF dominated the distribution patterns of PCDD/Fs in mussel

20 samples and these two congeners accounted for more than $70 \%$ of the $\sum 2,3,7,8$-PCDD/Fs.

21 This profile is similar to results previously published for mussels from other marine and

22 lake waters where the clear predominance of the two mentioned congeners was also 
1 observed (Petreas et al., 1992; Abad et al. 2003; Munschy et al., 2005b; Zhang and Jiang,

2 2005; Danis et al., 2006).

3 A very similar signal was observed when comparing the patterns from air (dominated

4 almost exclusive by the particulate phase), particle water phase and sediment. A similar

5 behavior has been observed in the sub-alpine Lake Maggiore where no local sources are

6 present and the PCDD/Fs and PCBs inputs to the water column and the sediments could be

7 attributed to long range transport and subsequence scavenging of atmospheric particulates

8 (Castro-Jiménez et al., 2005, 2008). The similar finding in Thau lagoon suggests a

9 predominant role of the atmosphere in the accumulation of PCDD/Fs in surface sediments

10 from this system.

11 The signal observed in mussels was different to the one exhibited by the other 12 compartments. Thus, whereas the signal observed for HpCDD, OCDD, HpCDF and OCDF

13 in the mussels was very similar to the one in the water and sediment (and also air), the

14 predominance of the low chlorinated PCDFs (specially the 2,3,7,8-TCDF) in mussels was

15 not observed in any of the other compartments (Figure 4). This fact could be interpreted as

16 a combined PCDD/Fs signal in mussels arriving in part from the water SPM but also from

17 the dissolved water phase, since mussels have been described to accumulate contaminants

18 both from the dissolved and particulate phases (Gossiaux et al., 1998). However, no

19 confirmation on the contribution from the dissolved water phase to this fingerprint could be

20 made with the available data, since it was only possible to determine the PCDD/Fs

21 dissolved water phase concentrations in one sample (RV) and most of the congeners were

22 below the LOD. Broman et al. (1991) reported a predominance of TCDFs in dissolved 
1 water phase in the Baltic Sea but very few data are available in the literature on PCDD/Fs

2 in the dissolved water phase.

$4 \quad P C B s$

5 Results on PCBs patterns are presented in Figure 5. As observed for PCDD/Fs, PCB air

6 patterns at both sites of the lagoon were very similar suggesting also a homogeneous

7 situation at both shores for this chemical group. When examining the patterns of the air gas

8 and particulate phases, low chlorinated congeners were predominant in the air gas phase

9 pattern, whereas higher chlorinated PCB were more abundant in the particulate air phase

10 pattern. Regarding PCB-118, although not reported (see QA/QC section) no predominance

11 for the samples in which this congener was measured was observed in the congener pattern.

12 The PCB pattern found in water showed a predominance of PCB-101 followed by PCB-52

13 in the dissolved water phase, whereas in the SPM phase, PCB-153 followed by PCB-138

14 were found predominant. Regarding surface sediment and mussel patterns, both matrixes

15 exhibited a predominance of PCB-153 followed by PCB-138. The fact that the pattern

16 found in all sampling location for each compartment (water, mussels and sediments) was

17 very similar suggests a homogeneous situation throughout the lagoon.

18 The predominance of hexachlorinated PCBs in mussels, especially PCB-153 and PCB-138,

19 has been reported in the literature for different coastal locations along the western

20 Mediterranean (Porte and Albaigés, 1993) and the Adriatic Sea (Bayarri et al., 2001;

21 Piersanti et al., 2006). Predominance of PCB-153 was reported from industrial and urban

22 impacted site sediments from Venice lagoon whereas for the less contaminated areas of the

23 lagoon, PCB-28 seemed to be predominant (Moret et al., 2001). Conversely, PCB-28 was 
1 found predominant in sediments from Taihu Lake in China and anthropogenic impacted site

2 (Zhang and Jiang, 2005).

3 Interestingly, when comparing the PCB pattern in the dissolved and particulate water

4 phases with the pattern exhibited in mussel and sediment, a similarity was observed only

5 with the particulate water phase (Figure 5). It seems that although the PCBs were

6 predominately found in the dissolved water phase, the resultant pattern in mussels reflected

7 better the one found in the SPM or sediments.

8 When comparing the patterns from air particulate phase, water SPM and sediments no

9 similarity was observed as occurred for PCDD/Fs. The predominance of PCB-153 observed

10 in SPM and sediment was not observed in air, where PCB-180 predominated. However, in

11 the case of PCBs, air-water exchange has been described as an important mechanism of 12 incorporation of these chemical to water bodies (Eisenreich and Looney, 1981;

13 Swackhamer et al., 1988) and this input way has not been evaluated in the present work.

\section{Conclusions}

16 PCDD/F and PCB air concentrations in Thau lagoon are typical of those reported for rural

17 or semi-rural sites in spite of this area has been described as an anthropogenic impacted

18 zone. Most probably the local meteorological conditions such as the strong wind regimes

19 affecting the lagoon area during the whole year (except summer months) favor these low air

20 concentrations. PCDD/F and PCB concentrations in the lagoon waters are low, especially

21 those for dioxins. PCDD/F and PCB sediment concentrations are in the range of those from

22 moderate urban/anthropogenic impacted areas, especially at the Eastern part of the lagoon.

23 Concentrations of $\mathrm{PCDD} / \mathrm{F}$, in all cases below the threshold set by the European 
1 Commission for fishery products for human consumption, and PCB in mussels point again

2 to a medium/moderate level situation.

3 The congener patterns of the studied POPs in the different environmental compartments

4 provide insight into the multi-media contamination distribution in a marine lagoon. The

5 patterns of $\mathrm{PCDD} / \mathrm{F}$ congeners in air, water particulate phase and sediments are very similar

6 suggesting direct coupling between these compartments. Therefore, PCDD/F atmospheric

7 inputs mainly associated to the air particle phase are expected to contribute to the total load

8 of PCDD/Fs in this aquatic system. However, for the same set of samples and available

9 data, no similarity is found for PCB congener patterns in air particulate phase relative to

10 those obtained in water phase (particulate and dissolved) and sediment. Further

11 investigation of other input mechanisms such as air-water exchange is needed to elucidate

12 the role of the atmosphere in the input of PCBs in this aquatic system.

13 The similarity of patterns observed in all sampling sites for each compartment (spatial

14 distribution) indicates a homogeneous situation in the lagoon and same type of source (s)

15 can be expected to affect the whole aquatic system. A complete year of air sampling,

16 including summer months and back trajectories analyses of air masses arriving to the area

17 are undergoing and will allow to more precisely evaluate the occurrence of airborne

$18 \mathrm{PCDD} / \mathrm{Fs}$ and PCBs in this coastal lagoon. 


\section{Acknowledgments}

2 This work was supported by Ifremer, by the Thresholds of Environmental Sustainability

3 Project (European Commission FP6, SUST-DEV, IP Project 003933-2) and the Agence de

4 l'eau Rhône-Méditerrannée-Corse. We thank all colleagues from Ifremer laboratory

5 LER/LR for their support with the sampling campaigns. We acknowledge our colleagues

6 from JRC-IES: Angelo Solimini from for his contribution regarding statistical data

7 analyses, Tania Huber for her assistant in the water samples analyses and Ingrid Vives for

8 her contribution reviewing the manuscript. We also thank Steven J. Eisenreich from JRC-

9 IHCP for his advice in the air sampling campaign design.

10

11

12 


\section{References}

2

3 Abad E., Pérez F., Llerena J.J., Saulo J., Caixach J., Rivera J., 2002. Study on

4 PCDDs/PCDFs and co-PCBs content in food samples from Catalonia (Spain).

5 Chemosphere, 46, 1435-1441.

6

7 Abad E, Pérez F, Llerena J J, Caixach J, Rivera J. 2003. Evidence for a specific pattern of

8 polychlorinated dibenzo-p dioxins and dibenzofurans in bivalves. Environmental Science

$9 \quad$ and Technology 37, 5090-5096.

10

11 Abad E., Caixach J., Rivera J., gustems L., Massagué G., Puig O. 2004. Temporal trends of

12 PCDDs/PCDFs in ambient air in Catalonia (Spain). Science of the Total Environment 334-

$13335,279-285$.

14

15 Abad E., Saulo J., Caixach J. and Rivera J., 2000. Evaluation of a new automated cleanup

16 system for the analysis of polychlorinated dibenzo- $p$-dioxins and dibenzofurans in

17 environmental samples. J. Chromatography A 893, 383-391.

18

19 Bayarri S., Baldassarri L.T., Iacovella N., Ferrara F., di Domenico A., 2001. PCDDs,

20 PCDFs, PCBs and DDE in edible marine species from the Adriatic Sea. Chemosphere, 43,

$21 \quad 601-610$.

22 
1 Breivik, K., Sweetman, A., Pacyna, J.M., and Jones, K.C., 2002. Towards a global

2 historical emission inventory for selected PCB congeners-a mass balance approach 2 .

3 Emissions. The Science of the Total Environment 290, 199-224.

4

5 Broman D., Näf c., Rolff C., Zebühr Y., 1991. Occurrence and dynamics of polychlorinated

6 dibenzo-p-dioxins and dibenzofurans and polycyclic aromatic hydrocarbons in the mixed

7 surface layer of remote coastal and offshore waters of the Baltic. Environmental Science

8 and Technology 25, 1850-1864.

10 Brubaker W.W. JR. and Hites R.A., 1997. Polychlorinated dibenzo-p-dioxins and 11 dibenzofurans: gas-phase hydroxyl radical reactions and related atmospheric removal. 12 Environmental Science and Technology 31, 1805-1810.

14 Bruzy L.P. and Hites, R.A.,1996. Global mass balance for polychlorinated dibenzo-p15 dioxins and dibenzofurans. Environmental Science and Technology 30, 1797-1804.

17 Bruhn R., and McLachlan M.S., 2002. Seasonal variation of polychlorinated biphenyl 18 concentrations in the souther part of the Baltic Sea. Marine Pollution Bulletin 44, 156-163.

20 Castro-Jiménez, J., Canuti, E., Christoph, E.H., Eisenreich, S.J., Hanke, G., Mariani, G., 21 Skejo, H., Umlauf, G., 2005. Tracing atmospheric deposition of PCDD/Fs in Lake 22 Maggiore (Italy): Preliminary results on settling material and sediments. Organohalogen 23 Compounds 67, 1209-1215. 
1 Castro-Jiménez, J., Mariani, G. , Eisenreich, S.J., Christoph, E.H., Hanke, G., Canuti, E.,

2 Skejo, H. and Umlauf, G. 2008. Atmospheric input of POPs into Lake Maggiore (Northern

3 Italy): PCDD/Fs and dioxin-like PCBs profiles and fluxes in the atmosphere and aquatic

4 system. Chemosphere 73, S122-S130.

5

6 Cleverly D., Ferrario J., Byrne C., Riggs K., Joseph D., Hartford P. 2007. A general

7 indication of the contemporary background levels of PCDDs, PCDFs and coplanar PCBs in

8 the ambient air over rural and remote areas of the United States. Environmental Science

9 and Technology 41, 1537-1544.

11 Cousins, I.T., and Jones K.C., 1998. Air-soil exchange of semi-volatile organic compounds 12 (SOCs) in the UK. Environmental Pollution 102, 105-118.

14 Currado G.M. and Harrad S. 2000. Factors influencing atmospheric concentrations of 15 polychlorinated biphenyls in Birmingham, U.K. Environmental Science and Technology $16 \quad 34,78-82$

18 Dalla Valle M, Marcomini A, Sfriso A, Sweetman A J, and Jones K C. 2003. Estimation of 19 PCDD/F distribution and fluxes in the Venice Lagoon, Italy: combining measurement and 20 modeling approaches. Chemosphere 51, 603-616.

22 Danis B., Debacker V., Trujilo Miranda C., Dubois Ph. 2006. Levels and effects of $23 \mathrm{PCDD} /$ Fs and co-PCBs in sediments, mussels, and sea stars of the intertidal zone in the 
1 southern North Sea and the English Channel. Ecotoxicology and Environmental Safety 65,

$2 \quad 188-200$.

3

4 Eisenreich S.J., and Looney B.B., 1981. Evidence for the atmospheric flux of 5 polychlorinated biphenyls to Lake Superior. In: D. Mackay, S. Peterson, S.J. Eisenreich and

6 M.S. Simmons (Eds), Physical behavior of PCBs in the Great Lakes. Ann Arbor science

7 Publishers, Ann Arbor, MI, pp 141-153.

8

9 Eljarrat E., De La Cal A., Larrazabal D., Fabrellas B., Fernandez-Alba A.R., Borrull F., 10 Marce R.M., Barcelo D., 2005. Occurrence of polybrominated diphenylethers, 11 polychlorinated dibenzo-p-dioxins, dibenzofurans and biphenyls in coastal sediments from 12 Spain. Environmental Pollution 136, 493-501.

14 European Commission, 2006. Commission Regulation (EC) No. 199/ 2006 of 3 February 152006 amending Regulation (EC) No. 466/2001 setting maximum levels for certain 16 contaminants in foodstuffs as regards dioxins and dioxin-like PCBs, Official Journal of the 17 European Communities L 32/34-38.

18

19 Gangnery A., Bacher C., Buestel D. 2001. Assessing the production and the impact of

20 cultivated oysters in the Thau lagoon (Mediterranee, France) with a population dynamics

21 model. Canadian Journal of Fisheries and Aquatic Sciences 58, 1012-1020. 
1 Gossiaux D.C., Landrum P.F., Fisher S.W. 1998. The assimilation of contaminants from

2 suspended sediment and algae by the Zebra Mussel, Dreissena polymorpha. 1998.

3 Chemosphere 36, 3181-3197.

4

5 Gambaro A., Manodori L., Moret I., Capodoglio G., Cescon P. 2004. Determination of

6 polychlorobiphenyls and polycyclic aromatic hydrocarbons in the atmospheric aerosol of

7 the Venice Lagoon. Analytical and Bioanalytical Chemistry 378, 1806-1814.

8

9 Gómez-Gutiérrez A., Garnacho E., Bayona J.M., Albaigés J. 2007. Assessment of the

10 Mediterranean sediments contamination by persistent organic pollutants. Environmental

11 Pollution 148, 396-408.

12

13 Harrad S.J. and Jones K.C., 1992. A source inventory and budget for chlorinated dioxins

14 and furans in the United Kingdom environment. The Science of the Total Environment $15 \quad 126,89-107$.

16

17 Harrad S. and Mao H. 2004. Atmospheric PCBs and organochlorine pesticides in 18 Birmingham, UK: concentrations, sources, temporal and seasonal trends. Atmospheric 19 Environment 38, 1437-1445.

20

21 Hashimoto S., Matsuda M., Wakimoto T., and Tatsukawa R., 1995. Simple sampling and

22 analysis of PCDDs and PCDFs in Japansese coastal seawater. Chemosphere 30, 1979-1986. 23 
1 Hornbuckle, K.C., Carlson, D.; Swackhamer, D.; Baker, J. and Eisenreich, S.J., 2006.

2 Polychlorinated Biphenyls in the Great Lakes. In: Persistent Organic Pollutants in the Great

3 Lakes (ed. Hites, R. A.), Handbook in environmental Chemistry Series, Springer-Verlag,

4 Heidelberg.

6 Johansson I, Moisan K, Guiot N, Truquet I, Munschy C, Tronczyński J. 2006.

7 Polybrominated diphenyl ethers (PBDEs) in mussels from selected French coastal sites:

8 1981-2003. Chemosphere 64, 296-305.

9

10 Knutzen J., Bjerkeng B., Naes K., Schlabach M., 2003. Polychlorinated 11 dibenzofurans/dibenzo-p-dioxins (PCDF/PCDDs) and other dioxin-like substances in 12 marine organisms from the Grenland fjords, S. Norway, 1975-2001: present contamination 13 levels, trends and species specific accumulation of PCDF/PCDD congeners. Chemosphere, $14 \quad 52,745-760$.

15

16 Lazure P.,1992. Etude de la dynamique de l'étang de Thau par modèle numérique 17 tridimensionnel.Vieet Milieu 42,137-145.

19 Léauté F., Tixier C., Munschy C., Tronczyński J. (2007) Present-day distributions and 20 background concentrations of persistent organic contaminants (PAHs and PCBs) in the 21 sediments of the Mediterranean lagoon (Thau) (to be submitted to Marine Pollution 22 Bulletin). 
1 Lee K.M., Kruse H., Wassermann O., 1996. The pattern of organochlorines in Mussels

2 Mytilus edulis L. from the South West Baltic Sea. Archives of Environmental

3 Contamination and .Toxicology 31, 68-76.

4

5 Legendre, Pierre \& Louis Legendre. 1998. Numerical ecology. $2^{\text {nd }}$ English Edition. Elsevier

6 Science BV, Amsterdam. Xv +853 pages.

8 Lohmann R., Brunciak P., Dachs J., Giglioti C.L., Nelson E., Van Ry D., Glenn T.,

9 Eisenreich S.J., Jones J.L. and Jones K.C., 2003. Processes controlling diurnal variations of 10 PCDD/Fs in the New Jersey coastal atmosphere. Atmospheric Environment 37, 959-969.

12 Lohmann R.; Green L.J.N., and Jones K.C., 1999. Detailed studies of the factors 13 controlling atmospheric PCDD/F concentrations. Environmental Science and Technology $1433,4440-4447$.

15

16 Lohmann R. and Jones K.C., 1998. Dioxins and furans in air and deposition: a review of 17 levels, behavior and processes. The Science of the Total Environment 219, 53-81.

19 Lohmann R., Nelson E., Eisenreich S.J. and Jones K.C., 2000. Evidence of dynamic air20 water exchange of PCDD/Fs: a study in the Raritan Bay/Hudson River Estuary. 21 Environmental Science and Technology 34, 3086-3093. 
1 Mandalakis M., Tsapakis M., and Stephanou E.G., 2001. Optimization and application of

2 high-resolution gas chromatography with ion trap tandem mass spectrometry to the

3 determination of polychlorinated biphenyls in atmospheric aerosols. Journal of

4 Chromatography 925, 183-196.

6 Mandalakis M., Tsapakis M., Tsoga A., and Stephanou E.G., 2002. Gas-particle

7 concentrations and distributions of aliphatic hydrocarbons, PAHs, PCBs and PCDD/Fs in

8 the Atmosphere of Athens (Greece). Atmospheric Environment 36, 4023-4035.

10 Manodori L., Gambaro A., Moret I., Capodoglio G., Cairns W.R.L., Cescon P. 2006.

11 Seasonal evolution of gas-phase PCB concentrations in Venice Lagoon Area. Chemosphere $12 \quad 62,449-458$.

14 Maldonado C., and Bayona J.M., 2002. Organochlorine compounds in the north-western 15 Black Sea water: distribution and water column process. Estuarine, Coastal and Shelf 16 Science 54, 527-540.

18 Moret I., Piazza R., Benedetti M., Gambero A., Barbante C., Cescon P. 2001. 19 Determination of polychlorobiphenyls in Venice Lagoon sediments. Chemosphere 43: 55920565.

22 Munschy C., Tronczyński J., Héas-Moisan K., Guiot N., Truquet I., 2005a. Analyse de 23 contaminants organiques (PCB, OCP, HAP) dans les organismes marins. Ed. ISBN 224 84433-144-0, Méthodes d'analyse en milieu marin, 44p.

26 Munschy C, Johansson I, Guiot N, Héas-Moisan K, Tronczyński J. 2005b. Retrospective 27 monitoring of the contamination of marine mussels from the French Coasts by PCDD/Fs 
1 (1981-2004). Organohalogen Compounds 67, 1243-1246.

2

3 Nixon S.W., 1982. Nutrients, primary production, and fisheries yields in coastal lagoons.

4 Oceanol.Acta 5, 357-371.

5

6 Pan J., Yang Y-L., Xu Q., Chen D-Z., Xi D-L. 2007. PCBs, PCNs and PBDEs in sediments

7 and mussels from Qingdao coastal sea in the frame of current circulations and influence of

8 sewage sludge. Chemosphere 66, 1971-1982.

9

10 Pearson R.F., Hornbuckle C., Eisenreich S.J., and Swackhamer D.L., 1996. PCBs in Lake

11 Michigan water revisited. Environmental Science and Technology 30, 1429-1436.

12

13 Petreas M.X., Wiesmüller T., Palmer F.H., Winkler J.J. and Stephens R.D. 1992. Aquatic life

14 as bimonitors of dioxins/furan and coplanar polychlorinated biphenyl contamination in the

15 Sacramento-San Joaquin river delta. Chemosphere 25, 621-631.

16

17 Piersanti A., Scrucca L., Galarini R., Tavolini T., 2006. Polychlorobiphenyls (18 congeners) in

18 mussels from middle Adriatic Sea. Organohalogen Compounds 68, 1951-1954.

19

20 Porte C., and Albaigés J. 1993. Bioaccumulation patterns of hydrocarbons and polychlorinated

21 biphenyls in bivalves, crustaceans, and fishes. Archives of Environmental Contamination and

22 Toxicology 26, 273-281.

23 
1 Réseau National d'Observation de la qualité du milieu marin littoral (RNO)

2 (http://www.ifremer.fr/envlit/surveillance/rno.htm)

3

4 Rose C.L., McKay W.A., 1996. PCDDs (dioxins) and PCDFs (furans) in selected UK lake

5 and reservoir sites-concentrations and TEQs in sediments and fish samples. The Science of

6 the Total Environment 177, 43-56.

7

8 Safe S., 1984. Polychlorinated biphenyls (PCBs) and polybrominated biphenyls (PBBs):

9 Biochemistry, toxicology and mechanism of action. Critical Reviews in Toxicology 13, $10 \quad 319-395$.

11

12 Safe S., 1990. Polychlorinated biphenyls (PCBs), dibdenzo-p-dioxins (PCDDs), 13 dibenzofurans (PCDFs) and related compounds: Environmental and mechanistic 14 considerations which support the development of toxic equivalency factors (TEFs). Critical 15 Reviews in Toxicology 21, 51-88.

16

17 Schwarzenbach, R. P., Gschwend, P. M., Imboden, D. M., 2003, Environmental Organic 18 Chemistry, 2nd Edition, Wiley Interscience, New York.

20 Simcik M.F., Basu I., Sweet C.W., Hites R.A. 1999. Temperature dependence and temporal

21 trends of polychlorinated biphenyl congeners in the Great Lakes atmosphere.

22 Environmental Science and Technology 33, 1991-1995. 
1 Suarez M.P., Rifai H.S., Palachek R. Dean, K., and Koening L., 2006. Distribution of

2 polychlorinated dibenzo-p-dioxins and dibenzofurans in suspended sediments, dissolved

3 phase and bottom sediment in the Houston ship Channel. Chemosphere 62, 417-429.

4

5 Swackhamer D.L., McVeety B.D., and Hites R.A., 1988. Deposition and evaporation of

6 polychlorinated biphenyls to and from Siskewit Lake, Isle Royale, Lake Superior.

7 Environmental Science and Technology 22, 664-672.

8

9 Totten L.A., Gigliotti C.L., Vanry D.A., Offenberg J.H., Nelson E.D., Dachs J., Reinfelder

10 J.R. and Eisenreich S.J., 2004. Atmospheric concentrations and deposition of

11 polychlorinated biphenyls to the Hudson River estuary. Environmental Science and

12 Technology 38, 2568-2573.

13

14 Tronczyński 1998 in Surveillance du milieu marin. Travaux du Réseau National

15 d'Observation du milieu marin. Edition 1998.

16

17 Tronczyński J., Catherine Munschy, Karine Moisan, Nadège Guiot, Isabelle Truquet,

18 Nathalie Olivier, Sophie Men and Audrey Furaut. 2004. Contamination of the Bay of

19 Biscay by polycyclic aromatic hydrocarbons (PAHs) following the T/V «Erika» oil spill.

20 Aquatic Living Resources 17, 243-259.

22 Tronczyński J., Munschy C., Héas-Moisan K., Guiot N., Truquet I., 2005a. Analyse de

23 contaminants organiques (herbicides, PCB, OCP, HAP) dans les eaux estuariennes et

24 marines côtières. Ed. ISBN 2-84422-148-3, Méthodes d'analyse en milieu marin, 52p. 
1 Tronczyński J., Munschy C., Héas-Moisan K., Guiot N., Truquet I., 2005b. Analyse de 2 contaminants organiques (PCB, OCP, HAP) dans les sédiments marins. Ed. ISBN 2-84433-

3 145-9, Méthodes d'analyse en milieu marin, 44p.

5 Tysklind M., Fangmark I., Marklund S., Lindskog A., Thaning L., and Rappe C., 1993.

6 Atmospheric transport and transformation of polychlorinated dibenzo-p-dioxins and

7 dibenzofurans. Environmental Science and Technology 27, 2190-2197.

9 U.S. EPA., 1994. Method 1613: Tetra-through Octa-Chlorinated Dioxins and Furans by 10 Isotope Dilution HRGC/HRMS.U.S. EPA., 1999. Method 1668, revision A: Chlorinated 11 Biphenyl Congeners in Water, Soil, Sediment and Tissue by HRGC/HRMS.

13 U.S. EPA., 1999. Method 1668, revision A: Chlorinated Biphenyl Congeners in Water, 14 Soil, Sediment and Tissue by HRGC/HRMS.

16 Van den Berg, M., Birnbaum L., Bosveld A.T.C., Brunström B., Cook P, Feeley M.,. Giesy

17 J.P., Hanberg A., Hasegawa R., Kennedy S.W., Kubiak T., Larsen J. C., van Leeuwen

18 R.F.X., Djien Liem A.K., Nolt C., Peterson R.E., Poellinger L., Safe S., Schrenk D., Tillitt

19 D., Tysklind M., Younes M., Wærn F., and Zacharewski T., 1998. Toxic Equivalency

20 Factors (TEFs) for PCBs, PCDDs, PCDFs for Humans and Wildlife. Environmental Health

21 Perspectives 106, 775-792.

23 Vives I., Canuti E., Castro-Jiménez J., Christoph E.H., Eisenreich S.J., Hanke G., Huber T., 24 Mariani G., Mueller A., Skejo H. Umlauf G., Wollgast J. 2007. Occurrence of 
1 polychlorinated dibenzo-p-dioxins and dibenzofurans ( $\mathrm{PCDD} / \mathrm{Fs})$, polychlorinated

2 biphenyls (PCBs) and polybrominated diphenyls ethers (PBDEs) in Lake Maggiore (Italy

3 and Switzerland). Journal of Environmental Monitoring 9, 589-598.

4

5 Wania F., Haugen J-E., Lei Y.D., Mackay D. 1998. Temperature dependence of

6 atmospheric concentrations of semivolatile organic compounds. Environmental Science and

7 Technology 32, 1013-1021.

8

9 Wodarg, D., Kömp P., McLachlan M.S., 2004. A baseline study of polychlorinated

10 biphenyl and hexachlorobenzene concentrations in the western Baltic Sea and Baltic

11 Proper. Marine Chemistry 87, 23-36.

12

13 Zeng E.Y., Peng, J., Tsukada D., and Ku T-L., 2002. In situ measurements of 14 polychlorinated biphenyls in the waters of San Diego Bay, California. Environmental 15 Science and Technology 36, 4975-4980.

16

17 Zhang Q., Jiang G. 2005. Polychlorinated dibenzo-p-dioxins/furans and polychlorinated 18 biphenyls in sediments and aquatic organisms from the Taihu Lake, China. Chemosphere $19 \quad 61,314-322$.

20

21 Zhou J.L., Maskaoui K., Qiu Y.W., Hong H.S., and Wang Z.D. 2001. Polychlorinated

22 biphenyl congeners and organochlorine insecticides in the water column and sediments of 23 Daya Bay, China. Environmental Pollution 113, 373-384. 
Table 1. Concentrations of PCDD/Fs in air $\left(\mathrm{fg} \mathrm{m}^{-3}\right)$, water column $\left(\mathrm{fg}^{-1}\right)$, surface sediments and mussels ( $\mathrm{pg} \mathrm{g}^{-1} \mathrm{dry}$ weight) found in Thau lagoon.

\begin{tabular}{|c|c|c|c|c|c|c|c|c|c|c|c|c|c|c|c|c|c|c|c|}
\hline \multirow{3}{*}{ Compounds } & \multicolumn{9}{|c|}{ Air (gas+particle phase) $\mathrm{fg} \mathrm{m}^{-3}$} & \multirow{2}{*}{\multicolumn{3}{|c|}{$\frac{\text { Mussel ( } \mathrm{pg} \mathrm{g}^{-1} \text { d.w.) }}{\text { May 04 }}$}} & \multirow{2}{*}{\multicolumn{2}{|c|}{$\frac{\text { Sediment ( } \mathrm{pg} \mathrm{g}^{-1} \text { d.w.) }}{\text { May 04 }}$}} & \multirow{2}{*}{\multicolumn{5}{|c|}{ Surface Water $\left(\mathrm{fg} \mathrm{l}^{-1}\right)^{* *}$}} \\
\hline & \multicolumn{5}{|c|}{ Site IF (14-18 Nov 05) } & \multicolumn{4}{|c|}{ Site BZ (15-18 Nov 05$)$} & & & & & & \multicolumn{3}{|c|}{ Nov 05 } & & \\
\hline & IF-1 & IF-2 & IF-3 & IF-4 & IF-5 & BZ-1 & BZ-2 & BZ-3 & BZ-4 & M1 & M4 & M2 & \multicolumn{2}{|c|}{\begin{tabular}{lc}
\multicolumn{3}{c}{ May 04 } \\
T10
\end{tabular}} & $\mathrm{T} 2$ & $\mathrm{C} 4$ & T11 & T12 & $\overline{\mathrm{RV}}$ \\
\hline 2,3,7,8-TCDD & $\leq 1.0^{*}$ & $\leq 1.0$ & $\leq 1.0$ & $\leq 1.0$ & $\leq 1.0$ & $\leq 1.0$ & $\bar{c} \leq 1.0$ & $\leq 1.0$ & 1.4 & nd & 0.1 & n.d. & 0.1 & 1.1 & $\leq 1.0$ & $\leq 0.7$ & $\leq 1.0$ & $\leq 1.0$ & $\leq 2.0$ \\
\hline $1,2,3,7,8-\mathrm{PeCDD}$ & 6.0 & 5.7 & 2.3 & 5.7 & 5.4 & 1.6 & 3.5 & 1.3 & 5.5 & 0.24 & nd & n.d. & 0.5 & 2.3 & $\leq 1.0$ & 2.8 & $\leq 1.0$ & $\leq 1.0$ & 4.0 \\
\hline $1,2,3,4,7,8-\mathrm{HxCDD}$ & 8.5 & 8.3 & 2.8 & 4.9 & 6.8 & 3.5 & 6.1 & 1.7 & 6.8 & 0.26 & $<0.07$ & n.d. & 0.4 & 2.1 & 3.5 & 2.8 & $\leq 2.0$ & $\leq 2.0$ & 9.6 \\
\hline $1,2,3,6,7,8-\mathrm{HxCDD}$ & 24.8 & 19.1 & 7.2 & 12.3 & 28.0 & 9.1 & 14.5 & 2.1 & 18.9 & 0.37 & $<0.06$ & 0.2 & 1.1 & 7.5 & 7.3 & 6.0 & $\leq 2.0$ & 4.3 & 24.1 \\
\hline $1,2,3,7,8,9-\mathrm{HxCDD}$ & 17.7 & 16.6 & 6.1 & 11.8 & 16.7 & 6.7 & 10.9 & 5.2 & 17.2 & 0.53 & 0.1 & 0.2 & 1.1 & 5.5 & 5.8 & 5.6 & $\leq 2.0$ & 2.8 & 21.6 \\
\hline $1,2,3,4,6,7,8-\mathrm{HpCDD}$ & 247.7 & 276.4 & 59.2 & 132.5 & 262.3 & 121.1 & 162.5 & 55.3 & 175.2 & 2.91 & 1.6 & 1.6 & 16.2 & 162.2 & 74.4 & 67.6 & 21.2 & 49.7 & 321.7 \\
\hline OCDD & 379.2 & 917.9 & 132.0 & 273.2 & 576.7 & 310.2 & 340.8 & 95.4 & 406.1 & 10.44 & 5.4 & 6.4 & 107.0 & 1270.1 & 266.6 & 320.1 & 114.1 & 350.4 & 1841.7 \\
\hline 2,3,7,8-TCDF & 6.7 & 7.1 & 2.4 & 4.9 & 6.0 & 2.5 & 1.6 & 1.2 & 2.3 & 2.7 & 3.5 & 4.0 & 2.9 & 12.6 & $\leq 1.0$ & $\leq 1.0$ & $\leq 1.0$ & $\leq 1.0$ & 40.0 \\
\hline $1,2,3,7,8-\mathrm{PeCDF}$ & 5.7 & 6.5 & 5.9 & 4.5 & 4.5 & 1.5 & 1.7 & 1.6 & 6.1 & 0.4 & 0.3 & 0.3 & 1.3 & 5.1 & $\leq 1.0$ & $\leq 1.0$ & $\leq 1.0$ & $\leq 1.0$ & 25.4 \\
\hline 2,3,4,7,8-PeCDF & 7.0 & 11.1 & 10.9 & 8.0 & 7.7 & 4.6 & 7.1 & 4.1 & 8.5 & 0.6 & 0.4 & 0.6 & 1.8 & 6.2 & $\leq 1.0$ & $\leq 1.0$ & $\leq 1.0$ & $\leq 1.0$ & 33.9 \\
\hline $1,2,3,4,7,8-\mathrm{HxCDF}$ & 8.9 & 11.1 & 10.0 & 6.9 & 7.9 & 5.3 & 18.2 & 3.2 & 11.8 & nd & 0.1 & 0.1 & 1.5 & 6.6 & $\leq 2.0$ & $\leq 2.0$ & $\leq 2.0$ & $\leq 2.0$ & 41.7 \\
\hline $1,2,3,6,7,8-\mathrm{HxCDF}$ & 5.5 & 6.6 & 9.9 & 6.3 & 4.8 & 4.0 & 7.6 & $\leq 1.0$ & 10.5 & nd & 0.2 & n.d. & 1.3 & 4.5 & 6.2 & 8.2 & $\leq 2.0$ & $\leq 2.0$ & 32.2 \\
\hline 2,3,4,6,7,8-HxCDF & 8.9 & 19.6 & 13.6 & 9.5 & 9.1 & 5.9 & 18.9 & $\leq 1.0$ & 13.2 & 0.4 & 0.2 & 0.2 & 2.0 & 6.2 & 10.9 & 8.3 & $\leq 2.0$ & 4.3 & 55.1 \\
\hline $1,2,3,7,8,9-\mathrm{HxCDF}$ & 2.8 & 6.5 & 4.2 & 2.4 & 3.4 & 2.1 & 4.2 & $\leq 1.0$ & 7.9 & 0.2 & $<0.06$ & n.d. & 0.3 & 1.4 & $\leq 2.0$ & $\leq 2.0$ & $\leq 2.0$ & $\leq 2.0$ & 14.3 \\
\hline $1,2,3,4,6,7,8-\mathrm{HpCDF}$ & 36.4 & 59.5 & 31.2 & 26.6 & 28.4 & 18.1 & 52.4 & 6.0 & 45.9 & 1.0 & 0.5 & 0.4 & 8.4 & 60.0 & 35.6 & 28.3 & $\leq 2.0$ & 10.9 & 175.0 \\
\hline $1,2,3,4,7,8,9-\mathrm{HpCDF}$ & 4.7 & 12.3 & 4.5 & 3.4 & 5.0 & 3.0 & 5.1 & $\leq 1.0$ & 4.8 & 0.3 & $<0.07$ & n.d. & 0.5 & 4.0 & 4.5 & 3.7 & $\leq 2.0$ & $\leq 2.0$ & 12.3 \\
\hline OCDF & 14.9 & 57.0 & 14.0 & 15.0 & 20.9 & 18.5 & 21.6 & 4.0 & 70.7 & 1.2 & 0.4 & 0.4 & 6.9 & 98.9 & 11.4 & 14.9 & $\leq 5.0$ & 15.4 & 118.9 \\
\hline$\sum 2,3,7,8-P C D D s$ & 684.9 & 1245.1 & 210.6 & 441.1 & 896.9 & 453.1 & 539.4 & 162.1 & 631.1 & 14.7 & 7.2 & 8.3 & 26.9 & 1450.7 & 359.6 & 405.7 & 143.3 & 411.2 & 2224.7 \\
\hline$\sum 2,3,7,8-P C D F s$ & 101.5 & 197.2 & 106.5 & 87.3 & 97.7 & 65.6 & 138.5 & 24.2 & 181.7 & 6.7 & 5.6 & 5.9 & 126.4 & 205.4 & 75.6 & 70.4 & 20.0 & 41.6 & 548.8 \\
\hline$\sum 2,3,7,8-\mathrm{PCDD} / \mathrm{Fs}$ & 786.4 & 1442.4 & 317.1 & 528.8 & 994.6 & 518.7 & 677.8 & 186.4 & 812.8 & 21.4 & 12.8 & 14.3 & 153.3 & 1656.1 & 435.2 & 476.1 & 163.3 & 452.8 & 2773.5 \\
\hline$W^{\prime} O_{98-} T E Q^{* * * *}$ & 22.1 & 25.7 & 15.8 & 18.4 & 21.7 & 10.4 & 18.6 & 6.9 & 22.6 & 1.0 & 0.7 & 0.8 & 2.89 & 13.8 & 7.6 & 8.7 & 4.3 & 5.3 & 53.4 \\
\hline
\end{tabular}


Table 2. Concentrations of the 7 ICES PCBs in air $\left(\mathrm{pg} \mathrm{m}^{-3}\right)$, water colum $\left(\mathrm{pg} \mathrm{l}^{-1}\right)$, surface sediments and mussels ( $\operatorname{pg~g}^{-1}$ dry weight) found in Thau lagoon.

\begin{tabular}{|c|c|c|c|c|c|c|c|c|c|c|c|c|c|c|c|c|c|c|c|c|}
\hline \multirow{3}{*}{ Compounds } & \multicolumn{9}{|c|}{ Air (gas+particle phase) $\mathrm{pg} \mathrm{m}^{-3}$} & \multirow{2}{*}{\multicolumn{3}{|c|}{$\frac{\text { Mussel ( } \mathrm{pg} \mathrm{g}^{-1} \text { d.w.) }}{\text { May } 04}$}} & \multirow{2}{*}{\multicolumn{3}{|c|}{$\frac{\text { Sediment (pg g }}{-1}$ d.w.) }} & \multirow{2}{*}{\multicolumn{5}{|c|}{$\frac{\text { Surface Water }\left(\mathrm{pg} \mathrm{l}^{-1}\right)^{* *}}{\text { Nov } 05}$}} \\
\hline & \multicolumn{5}{|c|}{ Site IF (14-18 Nov 05) } & \multicolumn{4}{|c|}{ Site BZ (15-18 Nov 05$)$} & & & & & & & & & & & \\
\hline & IF-1 & IF-2 & IF-3 & IF-4 & IF-5 & BZ-1 & $\mathrm{BZ}-2$ & BZ-3 & BZ-4 & M1 & M4 & M2 & $\mathrm{T} 3$ & $\mathrm{~T} 10$ & $\mathrm{~T} 12$ & $\mathrm{~T} 2$ & $\mathrm{C} 4$ & $\mathrm{~T} 11$ & $\mathrm{~T} 12$ & $\mathrm{RV}$ \\
\hline TrCB28 & 8.4 & 6.4 & 4.4 & 4.9 & 4.5 & 11.3 & 7.5 & 6.5 & 3.9 & 118 & 146 & 173 & 158 & 158 & 647 & 0.9 & 1.2 & 3.0 & 3.4 & 1.7 \\
\hline TeCB-52 & 8.9 & 7.8 & 5.0 & 5.3 & 4.9 & 11.2 & 6.0 & 5.3 & 4.1 & 92 & 209 & 254 & n.rs & 434 & 855 & 1.0 & 53.6 & 90.6 & 155.7 & 55.3 \\
\hline PeCB-101 & 8.3 & 7.7 & 5.6 & 5.1 & 6.9 & 10.3 & 5.9 & 5.3 & 4.5 & 955 & 1972 & 3543 & 252 & 299 & 5580 & 78.6 & 550.9 & 230.1 & 389.5 & 236.7 \\
\hline PeCB-118 & n.rp. & n.rp. & n.rp. & n.rp. & n.rp. & n.rp. & n.rp. & n.rp. & n.rp. & 802 & 1554 & 3327 & 347 & 479 & 5103 & 15.9 & 21.7 & 14.4 & 14.0 & 19.9 \\
\hline HxCB-153 & 10.0 & 10.3 & 7.2 & 6.5 & 11.1 & 11.8 & 7.7 & 6.3 & 5.8 & 5242 & 11107 & 18670 & 1115 & 1848 & 11346 & 18.8 & 36.6 & 30.7 & 37.3 & 31.1 \\
\hline HxCB-138 & 7.1 & 7.3 & 4.9 & 5.0 & 8.5 & 7.2 & 5.6 & 4.7 & 4.0 & 2305 & 6261 & 12229 & $441^{*}$ & $908^{*}$ & $7724 *$ & 15.8 & 24.8 & 20.1 & 22.0 & 28.2 \\
\hline НpCB-180 & 5.3 & 5.3 & 4.2 & 4.2 & 8.0 & 5.2 & 4.9 & 3.2 & 3.1 & 322 & 388 & 503 & 215 & 317 & 2064 & 6.6 & 19.8 & 13.1 & 13.8 & 16.8 \\
\hline$\sum$ PCBs & 48.1 & 45.0 & 31.2 & 31.0 & 43.9 & 56.9 & 37.6 & 31.3 & 25.4 & 9836 & 21637 & 38699 & 2528 & 4443 & 33319 & 137.6 & 708.5 & 402.2 & 635.6 & 389.7 \\
\hline
\end{tabular}

n rp = not reported; $n$ rs $=$ not well resolved; *CB138 quantified on DB5 column is not resolved with CB163/164

*** Values are the sum of particulate and dissolved phase concentrations 
Figure 1. Location of Thau Lagoon (France) and air, water, sediments and mussels sampling sites. Surface sediments and mussels were collected in May 2004 whereas air and water samples were collected in November 2005. Locations in the map are approximated 8 (see coordinates for exact location).

Figure 2. Wind directions and wind speeds registered during the sampling period $\left(14^{\text {th }}-19^{\text {th }}\right.$ November 2005) together with the daily sampled intervals for both sites. Temperature varied from 5 to $16^{\circ} \mathrm{C}$ during that period. Precipitation was registered on days $14^{\text {th }}$ and $15^{\text {th }}$. Data are from Météo France, station from Sète.

Figure 3. Principal components loading plot and correlation matrix among atmospheric variables and $\sum \mathrm{PCBs}$ and $\sum \mathrm{PCDD} / \mathrm{Fs}$ air concentrations during the sampling week. Values were expressed as mean over the $24 \mathrm{~h}$ period. Numbers are Pearson $\mathrm{R}^{2}(* \mathrm{p}<0.05)$.

Figure 4. Distribution pattern of PCDD/F congeners in air (sum of particuale + gas phases) in both sampling sites, particulate water phase (East, middle, mid-East and West sites), sediment (middle and East sites) and mussels samples (East, middle and West sites) from Thau lagoon.

Figure 5. Distribution pattern of PCB congeners in air gas phase $(\mathrm{G})$, particuale phase $(\mathrm{P})$, and total $(\mathrm{G}+\mathrm{P})$ in both air sampling sites, water dissolved phase (D), particulte phase (SPM) and whole water (D+SPM), sediment and mussels samples (East, middle and West sites) from Thau lagoon. G and P patters presented correspond to a selection of IF and BZ samples. 


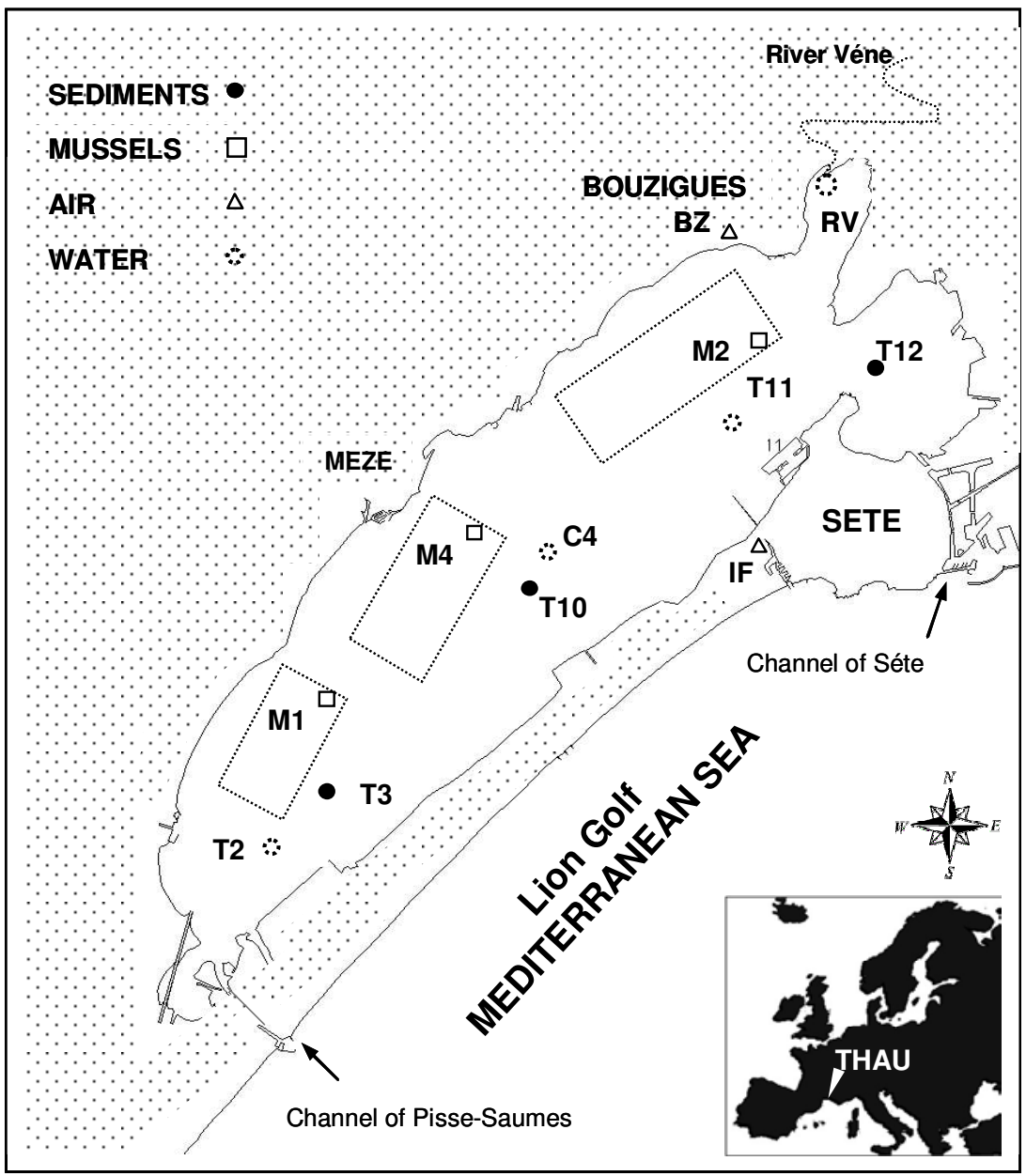

\begin{tabular}{ccccc} 
Code & Sample type & Latitude $(\mathrm{N})$ & Longitude $(\mathrm{E})$ & Depth $(\mathrm{m})$ \\
\hline $\mathbf{I F}$ & Air & $43^{\circ} 2351$ & $3^{\circ} 3934$ & Sea level \\
BZ & Air & $43^{\circ} 2626$ & $3^{\circ} 3901$ & Sea level \\
\hline RV & River water (outlet) & $43^{\circ} 2728$ & $3^{\circ} 4017$ & Surface \\
T12 & Lagoon water & $43^{\circ} 2579$ & $3^{\circ} 4102$ & 7.5 \\
T11 & Lagoon water & $43^{\circ} 2501$ & $3^{\circ} 3915$ & 8.5 \\
C4 & Lagoon water & $43^{\circ} 2403$ & $3^{\circ} 3670$ & 9 \\
T2 & Lagoon water & $43^{\circ} 2110$ & $3^{\circ} 3320$ & 4.5 \\
\hline M2 & Mussel & $43^{\circ} 2610$ & $3^{\circ} 3990$ & 1.5 \\
M4 & Mussel & $43^{\circ} 2526$ & $3^{\circ} 3738$ & 1.5 \\
M1 & Mussel & $43^{\circ} 2172$ & $3^{\circ} 3313$ & 1.5 \\
\hline T12 & Sediment & $43^{\circ} 2579$ & $3^{\circ} 4102$ & 7.5 \\
T10 & Sediment & $43^{\circ} 2500$ & $3^{\circ} 3801$ & 9 \\
T3 & Sediment & $43^{\circ} 2168$ & $3^{\circ} 3320$ & 4 \\
\hline
\end{tabular}




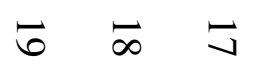

Cardin al points (degrees)

○

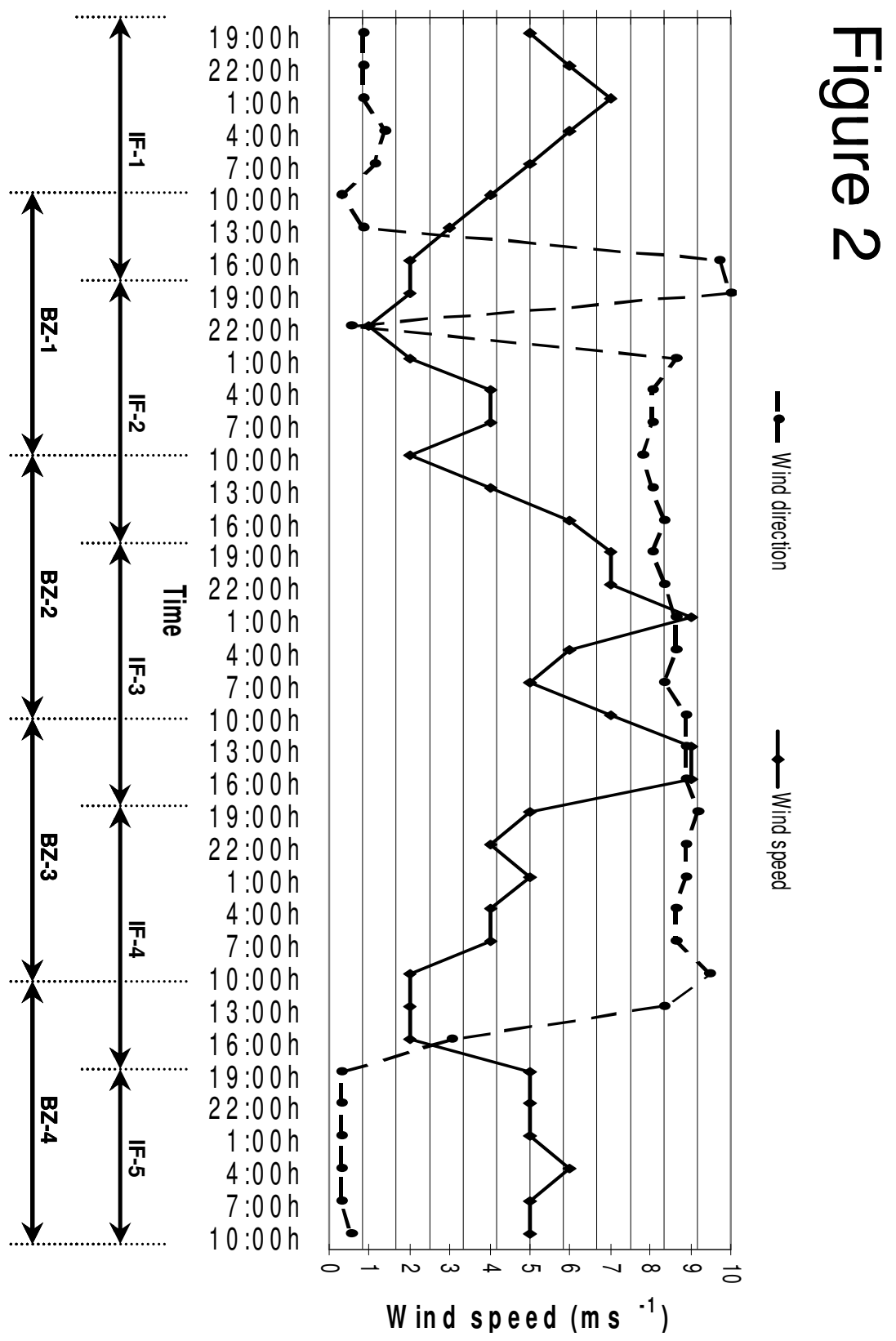


Figure 3

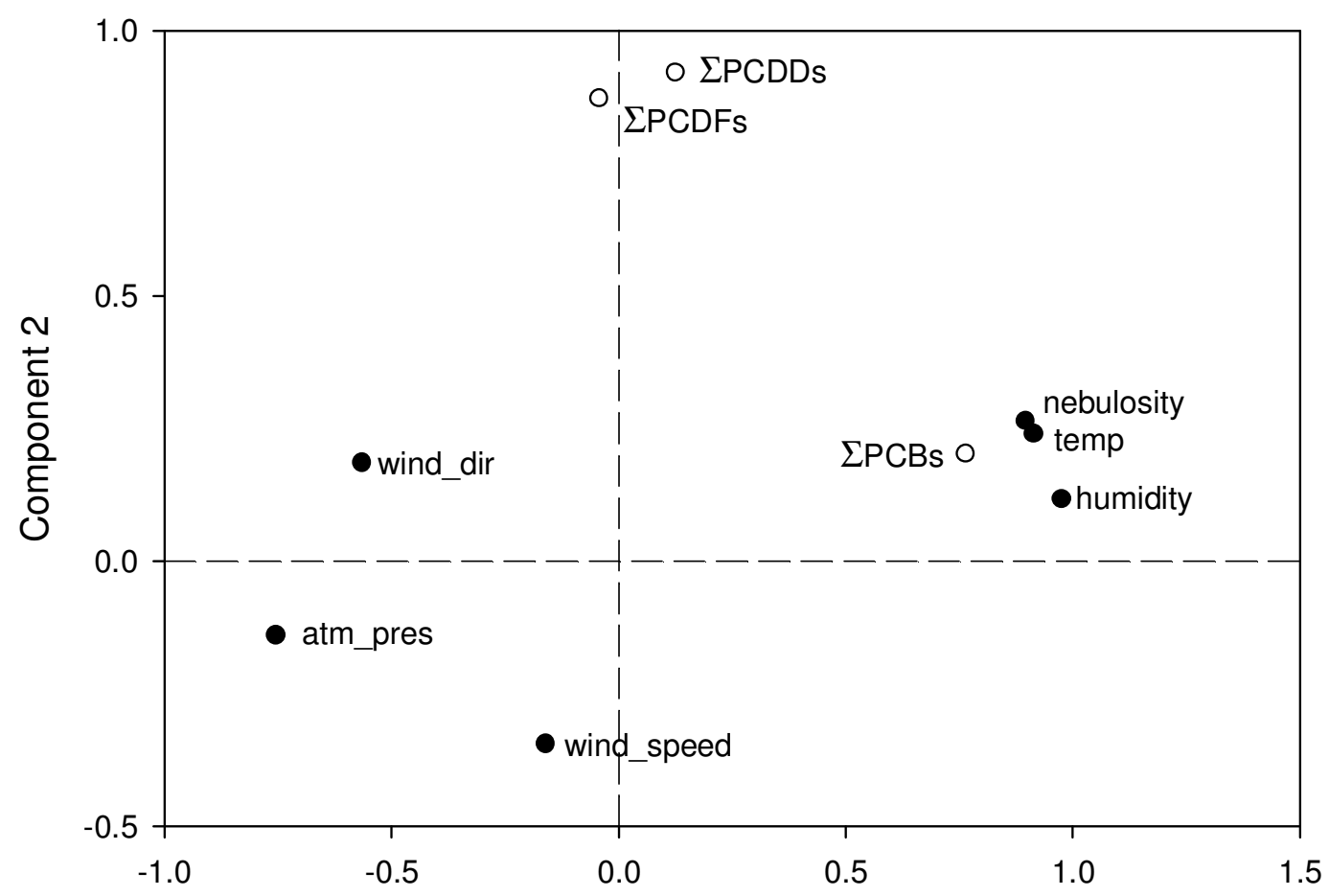

3

Component 1

\begin{tabular}{|c|c|c|c|c|c|c|c|c|}
\hline & Temperature & Nebulosity & Humidity & Atm.Press & Wind direction & Wind Speed & $\sum$ PCDDs & $\overline{\sum P C B s}$ \\
\hline$\overline{\text { Nebulosity }}$ & $0.9^{*}$ & & & & & & & \\
\hline Humidity & $0.9^{*}$ & $0.9^{*}$ & & & & & & \\
\hline Atm.Press & $-0.9 *$ & $-0.6^{*}$ & $-0.8^{*}$ & & & & & \\
\hline Wind direction & -0.3 & $-0.6^{*}$ & $-0.5^{*}$ & 0.1 & & & & \\
\hline Wind Speed & -0.1 & -0.1 & -0.3 & -0.1 & 0 & & & \\
\hline$\sum$ PCDDs & 0.2 & 0.4 & 0.2 & -0.1 & 0 & -0.3 & & \\
\hline$\sum \mathrm{PCBs}$ & $0.6^{*}$ & $0.8^{*}$ & $0.7 *$ & -0.4 & -0.3 & -0.5 & 0.4 & \\
\hline$\sum$ PCDFs & 0.3 & 0.2 & 0.1 & -0.2 & 0.1 & 0 & $0.7^{*}$ & -0.1 \\
\hline
\end{tabular}




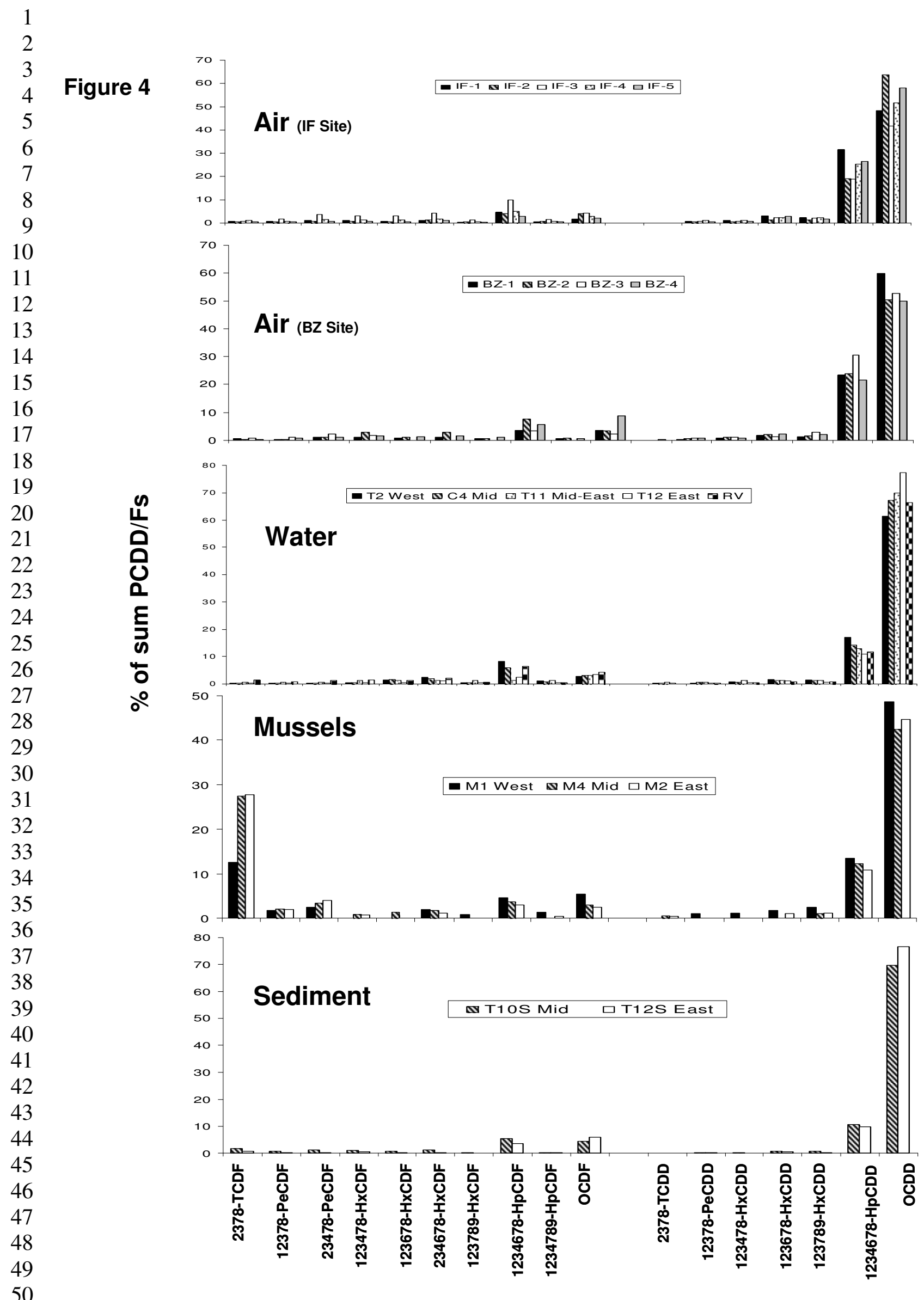




1
2
3
4
5
6
7
8
9
10
11
12
13
14
15

Figure 5
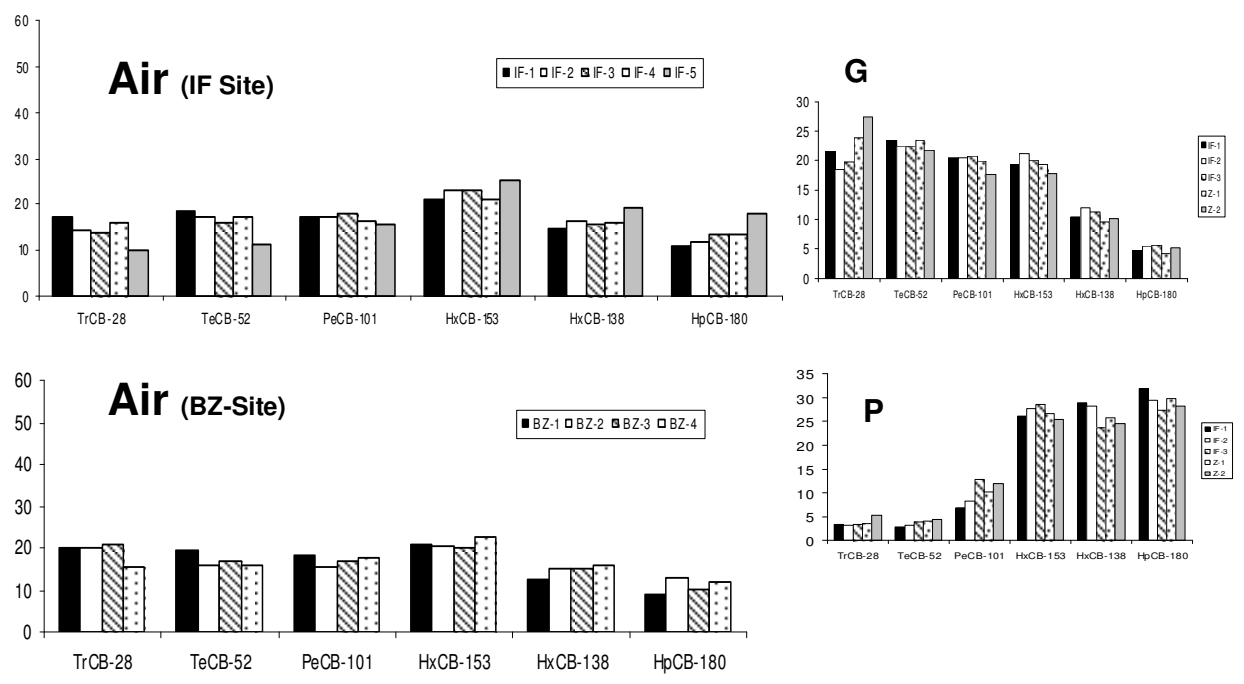

5

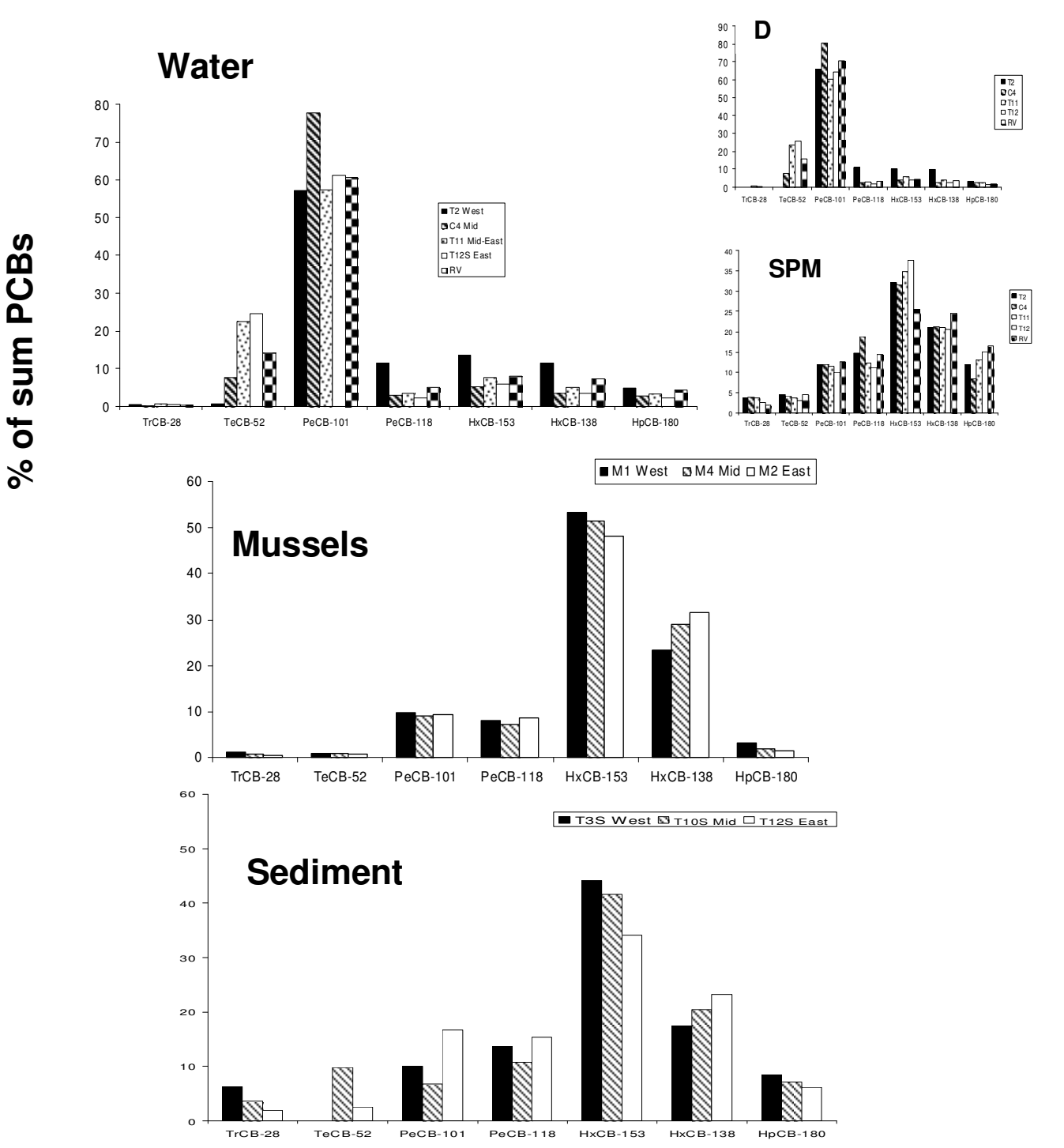

